\title{
Persistent millennial-scale link between Greenland climate and northern Pacific Oxygen Minimum Zone under interglacial conditions
}

\author{
O. Cartapanis ${ }^{1, *}$, K. Tachikawa ${ }^{1}$, O. E. Romero ${ }^{2, * *}$, and E. Bard ${ }^{1}$ \\ ${ }^{1}$ Aix-Marseille Université, CNRS, IRD, Collège de France, CEREGE UM34, 13545 Aix en Provence, France \\ ${ }^{2}$ Instituto Andaluz de Cs. de la Tierra (CSIC-UGR), Ave. de las Palmeras 4, 18100 Armilla-Granada, Spain \\ *now at: McGill University, Department of Earth and Planetary Sciences, 3450 University Street, Montreal, \\ H3A 0E8, Quebec, Canada \\ ** now at: MARUM, Center for Marine Environmental Sciences, University of Bremen, Leobener Str., \\ 28359 Bremen, Germany
}

Correspondence to: O. Cartapanis (olivier.cartapanis@mcgill.ca)

Received: 12 June 2013 - Published in Clim. Past Discuss.: 11 July 2013

Revised: 9 January 2014 - Accepted: 18 January 2014 - Published: 27 February 2014

\begin{abstract}
The intensity and/or extent of the northeastern Pacific Oxygen Minimum Zone (OMZ) varied in-phase with the Northern Hemisphere high latitude climate on millennial timescales during the last glacial period, indicating the occurrence of atmospheric and oceanic connections under glacial conditions. While millennial variability was reported for both the Greenland and the northern Atlantic Ocean during the last interglacial period, the climatic connections with the northeastern Pacific OMZ has not yet been observed under warm interglacial conditions. Here we present a new geochemical dataset, spanning the past $120 \mathrm{ka}$, for major components (terrigenous fraction, marine organic matter, biogenic opal, and carbonates) generated by X-ray fluorescence scanning alongside with biological productivity and redox sensitive trace element content (Mo, Ni, Cd) of sediment core MD02-2508 at $23^{\circ} \mathrm{N}$, retrieved from the northern limit of the modern OMZ. Based on elemental ratios $\mathrm{Si} / \mathrm{Ti}$ (proxy for opal), $\mathrm{Cd} / \mathrm{Al}$ and $\mathrm{Ni} / \mathrm{Al}$, we suggest that biological productivity was high during the last interglacial (MIS5). Highly resolved opal reconstruction presents millennial variability corresponding to all the Dansgaard-Oeschger interstadial events over the last interglacial, while the Mo/Al ratio indicates reduced oxygenation during these events. Extremely high opal content during warm interstadials suggests high diatom productivity. Despite the different climatic and oceanic background between glacial and interglacial periods, rapid variability in
\end{abstract}

the northeastern Pacific OMZ seems to be tightly related to Northern Hemisphere high latitude climate via atmospheric and possibly oceanic processes.

\section{Introduction}

Oxygen Minimum Zones (OMZ) develop in areas where oxygen consumption by organic matter degradation in the water column and on the seafloor outmatches lateral/vertical advection/diffusion of dissolved oxygen. Thus, intermediate depth OMZ variations are mainly determined by (1) variations of the oxygen content in source intermediate water masses, (2) changes in rate of intermediate water formation and advection, and/or (3) oxygen consumption occurring during the flow of intermediate water masses toward the OMZ and within the OMZ itself (Karstensen et al., 2008; Paulmier and Ruiz-Pino, 2009; Stramma et al., 2010a). Oxygen consumption is related to the degradation of organic matter as it sinks through the water column and settles on the seafloor (Karstensen et al., 2008).

During the past decades, the scientific community has put considerable effort in understanding the past dynamics of the OMZ, owing to its potential role in the carbon cycle and greenhouse gas Emissions (Paulmier et al., 2008, 2011), and the global marine nitrogen cycle (Galbraith et al., 2004). The modern expansion of the OMZ, probably in relation to 
anthropogenic climate change (Stramma et al., 2008, 2010b), points out the importance of understanding the factors that influence OMZ dynamics in an abrupt climate change context, as it could behave as an internal feedback on the global climate (Altabet et al., 2002; Pichevin et al., 2007).

The variability of the mid-latitude north Pacific OMZ during the last glacial period has been extensively studied (Hendy and Pedersen, 2005; Dean, 2007; Hendy, 2010; Cartapanis et al., 2011, 2012). Most of these studies revealed a strong link between oxygen deficit in the northern Pacific and Northern Hemisphere high latitude climate on millennial timescales, with enhanced oxygen depletion and higher biological productivity during warm Dansgaard-Oeschger (DO) interstadial events, and enhanced oxygenation during Heinrich events (HE). Both biological productivity and oceanic ventilation are suspected to have influenced past OMZ variations (Hendy and Kennett, 2000; Hendy et al., 2004; Cartapanis et al., 2011, 2012). In particular, modelling studies indicate that the disruption of North Atlantic Deep Water formation during $\mathrm{HE}$ was associated with an increase of the oxygenation in the northern Pacific. North Pacific Intermediate Waters (NPIW) formation/oxygenation increased, enhancing oxygen advection towards the OMZ, while a reduction of the deep upwelling of nutrient rich waters reduced productivity and associated oxygen consumption at low latitudes (Schmittner, 2005; Schmittner et al., 2007).

Climate variability during the last interglacial (Marine Isotopic Stage $=$ MIS5) is particularly interesting because of climatic similarities with the Holocene. However, productivity and ventilation variations during MIS5 have been poorly documented so far. Except for MIS5e, MIS5 is characterised by lower sea level than during full interglacial periods (e.g. Holocene and MIS5e), but higher sea level than during glacial (e.g. MIS2, 3 and 4) (Lambeck et al., 2002; Waelbroeck et al., 2002; Cutler et al., 2003; Hu et al., 2010; Grant et al., 2012). This suggests the existence of a small but significant ice cap over Northern Hemisphere high latitude continents (Bonelli et al., 2009; Ganopolski et al., 2010). During MIS5, DO (Johnsen et al., 2001) and HE-like events (massive iceberg discharge in the North Atlantic) (McManus et al., 1994; Eynaud et al., 2000; Oppo et al., 2006) occurred together with rapid high amplitude sea level changes (Grant et al., 2012).

A few studies in the northeastern Pacific suggested higher productivity (Ganeshram and Pedersen, 1998; Kienast et al., 2002) and lower oxygenation at intermediate depth (Nameroff et al., 2004) during MIS5 as compared to glacial periods (MIS2 to MIS4). However, the millennial scale variations of productivity and oxygenation in North Pacific OMZ over the last interglacial remain unknown because of scarce high-resolution records.

Siliceous organisms such as diatoms represent a significant proportion of the production in the Pacific, but the mechanisms responsible for spatial and temporal variations of diatoms productivity (e.g. wind driven upwelling, nutrient con- tent of water masses, biological competition for nutrients use) remain controversial and are likely related to changes in atmospheric and oceanic circulation. While several studies displayed millennial and/or glacial/interglacial changes of the opal production at low latitude in the eastern Pacific (Ganeshram and Pedersen, 1998; Kienast et al., 2006; Dubois et al., 2010; Pichevin et al., 2010; Arellano-Torres et al., 2011; Dubois et al., 2011; Romero et al., 2011a; Cartapanis et al., 2012), high temporal resolution opal records in northeastern Pacific are still limited.

Here we present a new geochemical dataset spanning the last $120 \mathrm{ka}$ from the northern edge of the modern North Pacific OMZ. High-resolution X-ray fluorescence (XRF) measurements for major sediment components (marine organic carbon, opal, carbonates and terrigenous fraction), were performed on MD02-2508 core (MD08, northeastern coastal Pacific), in order to monitor the past productivity variations. Trace element response to productivity and bottom water oxygenation were measured by ICP-MS in an attempt to reconstruct past variability of the $\mathrm{OMZ}$ and to determine the factors driving its variations. High sedimentation rate at site MD08 during MIS5 (around $35 \mathrm{~cm} \mathrm{ka}^{-1}$ ) provides a unique opportunity to reconstruct the millennial scale variability of productivity and ventilation during the last interglacial period, and the mechanisms involved in linking high latitude climate variations to lower latitude climate, oceanic conditions, and biogeochemical cycles.

\section{Materials and method}

Core MD08 $\left(23^{\circ} 27.91^{\prime} \mathrm{N}, 111^{\circ} 35.74^{\prime} \mathrm{W}, 606 \mathrm{~m}\right.$ water depth, Fig. 1) was retrieved from the Baja California margin by the R.V. Marion-Dufresne during the coring campaign IMAGES MD126-MONA. Detailed analytical procedures are shown in a previous study (Cartapanis et al., 2011). In order to trace the past $\mathrm{OMZ}$ dynamics, we measured $\mathrm{Br}$ and $\mathrm{Si} / \mathrm{Ti}$, representative of the marine organic matter (Mayer et al., 2007) and opal content, respectively, and $\mathrm{Ca}$ and $\mathrm{Ti}$, representative of the carbonates and the terrigenous sediment fractions respectively. XRF measurements were performed using ITRAX XRF core scanner (Cox Analytical Systems) with both Mo $(30 \mathrm{kV}$ and $45 \mathrm{~mA})$ and $\mathrm{Cr}(35 \mathrm{kV}$ and $35 \mathrm{~mA}) \mathrm{X}-$ ray sources, with a counting time of $15 \mathrm{~s}$. XRF measurement resolution was increased in the presence of lamination (from $0.5 \mathrm{~cm}$ to $200 \mu \mathrm{m}$ ) and is equivalent to $2 \mathrm{yr}$ on average. Discrete bulk sediment samples were dissolved by acid digestion and elemental concentrations $(\mathrm{Cd}, \mathrm{Mo}, \mathrm{Ni}, \mathrm{Ti}, \mathrm{Ca}$, and $\mathrm{Al})$ were analysed by ICP-MS (Agilent 7500ce). Trace elements contents $(\mathrm{Cd}, \mathrm{Mo}, \mathrm{Ni})$ are normalized against $\mathrm{Al}$ to estimate authigenic enrichment. Temporal resolution of these measurements is better than $500 \mathrm{yr}$. While $\mathrm{Cd}$ and $\mathrm{Ni}$ are closely associated with biogenic sinking particles, Mo accumulation in the sediment is instead associated with redox condition at bottom water/sediment interface (Nameroff et al., 


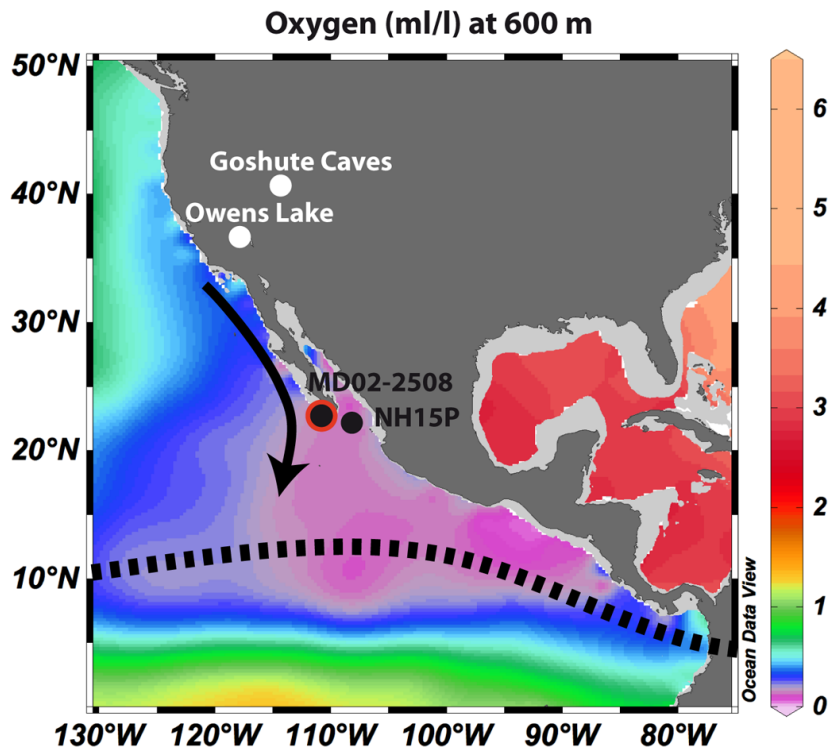

Fig. 1. Dissolved oxygen content at $600 \mathrm{~m}$ in northeastern $\mathrm{Pa}-$ cific (World Ocean Atlas 09, Garcia et al., 2010) and positions of the records discussed in the text. Cores MD02-2508 (this study); NH15P (Ganeshram and Pedersen, 1998; Nameroff et al., 2004); Goshute Cave (Denniston et al., 2007); Owens Lake (Li et al., 2004). Black arrow indicates dominant winds during upwelling season and black dotted line represents ITCZ position during boreal summer. Figure 1 was generated using the Ocean Data View software (http://odv.awi.de).

2002; Tribovillard et al., 2006; Cartapanis et al., 2011). We thus use $\mathrm{Cd} / \mathrm{Al}$ and $\mathrm{Ni} / \mathrm{Al}$ as productivity indicators, and $\mathrm{Mo} / \mathrm{Al}$ as an oxygenation indicator. The terrigenous fraction of the sediment was calculated using Ti content in the mean Upper Continental Crust (UPC, $4100 \mu \mathrm{g} \mathrm{g}^{-1}$, McLennan, 2001). Total organic carbon (TOC) was determined using a FISONS NA 1500 elemental analyser after carbonates were removed with $1 \mathrm{M} \mathrm{HCl}$. All the elemental analyses and organic carbon determination were carried out at CEREGE (Aix en Provence, France).

Samples for the analysis of opal were freeze-dried and ground in an agate mortar. Opal content was determined by the sequential leaching technique of DeMaster (1981) and by molybdate-blue spectrophotometry, with further modifications by Müller and Schneider (1993). Opal measurements were performed at MARUM (Bremen, Germany).

The age model of the core is based on previously published studies. Given a known relationship between sediment physical property variation and high latitude climate variability at southern Baja California margin (Ortiz et al., 2004; Dean et al., 2006; Dean, 2007; Marchitto et al., 2007), we used a visual correlation of wet bulk density obtained from the GEOTEK logger and lightness obtained by spectrophotometry (Beaufort et al., 2002) to the NGRIP isotopic oxygen record (Johnsen et al., 2001) for the past $70 \mathrm{ka}$ (see details in Leduc (2007), Cartapanis et al. (2011) and in Table 1). One
Table 1. Tie points (corrected depth in $\mathrm{cm}$, age in year B.P.), method and references used to build the age model of MD02-2508 core in this study.

\begin{tabular}{rrll}
\hline $\begin{array}{r}\text { Corrected } \\
\text { depth (cm) }\end{array}$ & $\begin{array}{r}\text { Age } \\
\text { (yr B.P.) }\end{array}$ & Method & Reference \\
\hline 0 & 0 & NGRIP visual correlation & Cartapanis et al. (2011) \\
500 & 11450 & NGRIP visual correlation & Cartapanis et al. (2011) \\
592 & 14550 & NGRIP visual correlation & Cartapanis et al. (2011) \\
892 & 28500 & NGRIP visual correlation & Cartapanis et al. (2011) \\
980 & 33500 & NGRIP visual correlation & Cartapanis et al. (2011) \\
1014 & 35300 & NGRIP visual correlation & Cartapanis et al. (2011) \\
1082 & 38250 & NGRIP visual correlation & Cartapanis et al. (2011) \\
1168 & 41700 & NGRIP visual correlation & Cartapanis et al. (2011) \\
1218 & 43600 & NGRIP visual correlation & Cartapanis et al. (2011) \\
1306 & 47300 & NGRIP visual correlation & Cartapanis et al. (2011) \\
1514 & 54950 & NGRIP visual correlation & Cartapanis et al. (2011) \\
1656 & 59100 & NGRIP visual correlation & Cartapanis et al. (2011) \\
3689 & 117000 & Blake magnetic excursion & Blanchet et al. (2007) \\
\hline
\end{tabular}

additional tie point was added for the Blake magnetic excursion $(115-122 \mathrm{ka})$ identified in MD08 core by Blanchet et al. (2007) (see crosses at the top of Fig. 2 and Table 1).

\section{Study area}

The intertropical Pacific hosts the most extended modern OMZ (Paulmier and Ruiz-Pino, 2009, see also Fig. 1). Oxygen depletion is even more pronounced in the northern $\mathrm{Pa}$ cific, because of restrained NPIW formation in the Okhotsk sea (Talley, 1991; Shcherbina et al., 2003) as compared to the southern Pacific where Antarctic Intermediate Water (AAIW) ventilates the intermediate depth more efficiently. MD08 core was retrieved off the Baja California margin, at the southern limit of the NPIW in the eastern Pacific (Fig. 1, see details in Cartapanis et al., 2011). Further south, intermediate depths are occupied by the Equatorial Pacific Intermediate Waters, mainly derived from AAIW and Pacific Deep Waters (Bostock et al., 2010). At the surface, the California Current (CC) that transports relatively fresh and cold Subarctic Water (SW) along eastern Pacific coast is diverted westward and slowly sinks in the water column around $25^{\circ} \mathrm{N}$, slightly north of MD08 core (Auad et al., 2011).

Presently, the productivity of diatoms and small phytoplankton (as defined by Moore et al., 2004, and which include Coccolithophoridae), is thought to be limited by nitrate content in surface waters (Moore et al., 2004). Wind driven upwelling activity related to atmospheric circulation is an important driver of the modern productivity along northeastern Pacific shores (Lynn and Simpson, 1987; Thomas et al., 2001; Zaytsev et al., 2003; Pennington et al., 2006). During summer, the North Pacific high-pressure cell strengthens and the continental low deepens, resulting in a high eastwest pressure gradient inducing equatorward winds. Modern productivity off northeastern Pacific shores is consequently higher during summer months when alongshore southward 


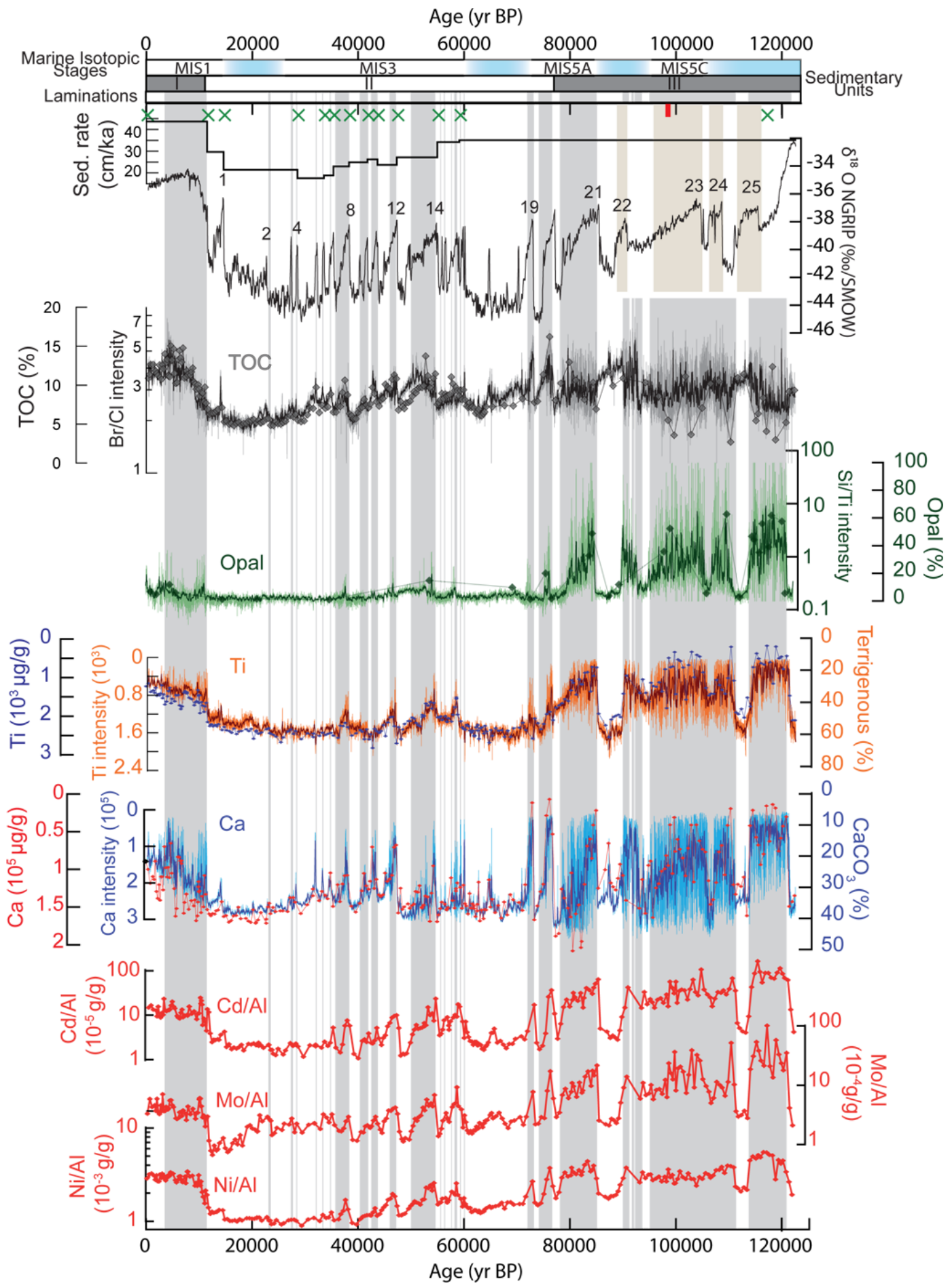

Fig. 2. The sedimentation rate in MD08 core; the isotopic composition of NGRIP ice core ( $\delta^{18}$ O\%o/SMOW) (NGRIP Members, 2004); the $\mathrm{Br} / \mathrm{Cl}$ based marine organic matter high resolution record for MD02-2508 core calibrated using TOC measurements on the same core (the TOC data were first reported by Blanchet et al. (2007), and 40 additional TOC measurements were added from 120 to $60 \mathrm{ka}$ ). Si / Ti record calibrated using opal measurements (green diamonds). Ca measurements (XRF scan and ICP-MS), converted into carbonate content considering that all the Ca belongs to the carbonate phase. Ti XRF and ICP-MS records converted into terrigenous matter content calculated using mean Ti content in the upper continental crust (McLennan, 2001). Note that $\mathrm{Ca}$ and Ti scales are reversed. Cd/ $\mathrm{Al}, \mathrm{Mo} / \mathrm{Al}$, and Ni / $\mathrm{Al}$ measured using ICP-MS on log scale. Green crosses at the top of the figure indicate tie points used to build the age model. Marine isotopic stages and sedimentary units as described in part 3 are indicated. Grey vertical bars highlight the laminated layers. Red tick at the top of the figure indicates the position of the sample displayed in Fig. 3. 


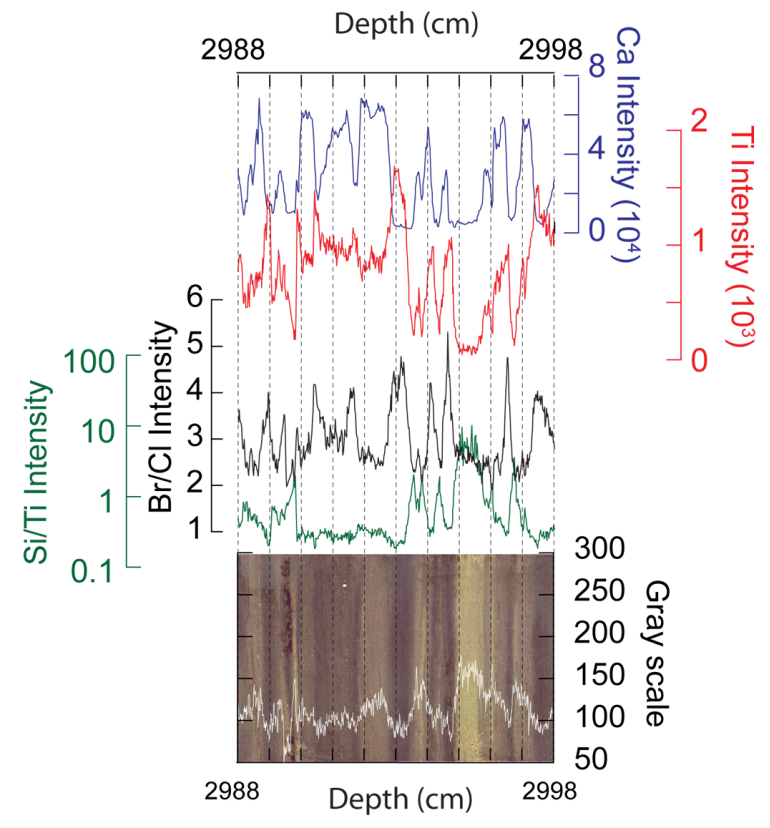

Fig. 3. The $\mathrm{XRF}$ intensities for $\mathrm{Ca}, \mathrm{Ti}, \mathrm{Br} / \mathrm{Cl}$, and $\mathrm{Si} / \mathrm{Ti}$ (spatial resolution of $200 \mu \mathrm{m}$ ) of a $10 \mathrm{~cm}$ long sample of MD02-2508, representing roughly $300 \mathrm{yr}$ of sediment deposition, and the corresponding photography of the core with gray scale analyses. Contrast and lightness of the image were slightly enhanced, and gray scale measurements were performed using ImageJ software. The position of the sample within the record is indicated with a red tick at the top of Fig. 2. Vertical dashed lines show $1 \mathrm{~cm}$ intervals.

winds are enhanced (Fig. 1, Thomas et al., 2001). Despite the influence of local bottom topography and angular orientation of the coastline, upwelling is stronger during early summer at MD08 core (Zaytsev et al., 2003; Cartapanis et al., 2011). Upwelled waters originate from up to $300 \mathrm{~m}$ depth along the California coast (van Geen and Husby, 1996), at the mixing zone between SW and NPIW. Thus, NPIW nutrient inventory related to tidal mixing at high northern latitude in the Pacific (Sarmiento et al., 2004), might influence surface productivity. High local productivity is thus associated with warm condition on seasonal timescales when the Intertropical Convergence Zone (ITCZ) is situated on its northern position.

\section{Results}

Highly resolved XRF $\mathrm{Si} / \mathrm{Ti}$ (log-scale) is well correlated $\left(R^{2}=0.93\right)$ to opal content obtained by chemical leaching of bulk sediments (Fig. 2). Br is contained in marine organic matter, but also in pore water (Ziegler et al., 2008). Since pore water content in opal-rich sediment is strongly affected by opal concentration, we used $\mathrm{Br} / \mathrm{Cl}$ ratio as indicator of marine organic matter to correct pore water contribution using $\mathrm{Cl}$ (Croudace et al., 2006). $\mathrm{Log} \mathrm{Br} / \mathrm{Cl}$ is well
Table 2. Minimal, maximal, and mean values for $\mathrm{Al}$ content $\left(\mu \mathrm{g} \mathrm{g}^{-1}\right), \mathrm{Cd} / \mathrm{Al}, \mathrm{Mo} / \mathrm{Al}$, and Ni/Al in MD08 core. Mean values in Upper Continental Crust (McLennan, 2001) and mean enrichment factors ((Mean Element / $\left.\mathrm{Al})_{\mathrm{MD} 08} /(\text { Element / } \mathrm{Al})_{\mathrm{UPC}}\right)$ are displayed at the bottom of the table.

\begin{tabular}{lrccc}
\hline & $\mathrm{Al}\left(\mu \mathrm{g} \mathrm{g}^{-1}\right)$ & $\mathrm{Cd} / \mathrm{Al}\left(\mathrm{g} \mathrm{g}^{-1}\right)$ & $\mathrm{Mo} / \mathrm{Al}\left(\mathrm{g} \mathrm{g}^{-1}\right)$ & $\mathrm{Ni} / \mathrm{Al}\left(\mathrm{g} \mathrm{g}^{-1}\right)$ \\
\hline Min & 3200 & $2.77 \times 10^{-5}$ & $1.32 \times 10^{-4}$ & $1.38 \times 10^{-3}$ \\
Max & 51813 & $4.21 \times 10^{-3}$ & $2.00 \times 10^{-2}$ & $8.49 \times 10^{-3}$ \\
Mean & 32343 & $3.97 \times 10^{-4}$ & $1.30 \times 10^{-3}$ & $3.41 \times 10^{-3}$ \\
UPC & 80400 & $1.22 \times 10^{-6}$ & $1.87 \times 10^{-5}$ & $5.47 \times 10^{-4}$ \\
Enrichment & & 326 & 70 & 6 \\
Factor & & & & \\
\hline
\end{tabular}

correlated $\left(R^{2}=0.68\right)$ to TOC content (Fig. 2). The MD08 sediment column is divided in three different units (Fig. 2). The first unit (Unit I) that corresponds to the Holocene consists of laminated high TOC $(\approx 13 \%)$, relatively low carbonates $(\approx 20 \%)$ and terrigenous compounds $(\approx 45 \%)$ sapropelic mud (Fig. 2). The second unit (Unit II) was deposited during MIS2, 3 and 4, and is composed of light homogenous calcareous clay (carbonates $\approx 35 \%$, terrigenous $\approx 60 \%$, and TOC $\approx 7 \%$ ). Interbeds of dark laminated sapropelic mud similar to Unit I (Fig. 2) were deposited during interstadial events (Cartapanis et al., 2011). Opal content within Units I and II is low $(0$ to $10 \%)$ but is higher within laminated intervals (up to $20 \%$, Fig. 2). The third unit (Unit III) corresponds to MIS5 and mainly consists of laminated sapropelic diatom ooze (Fig. 3) with some homogenous layers composed of calcareous clays, similar to Unit II non-laminated sediment (Fig. 2). The millimetric to centimetric laminations in the Unit III are composed of light colour biogenic remains, and dark coloured organic matter mixed with terrigenous sediment (Fig. 3). Opal content rises up to $40 \%$ in MIS5 laminations and reaches over $80 \%$ in particular laminations (Fig. 2). Micro sedimentologic analyses suggest that high opal content laminae in Unit III were deposited abruptly, and could correspond to algal blooms during upwelling events or in the frontal zone between water masses of different densities (Murdmaa et al., 2010).

Trace element $(\mathrm{Cd}, \mathrm{Mo}, \mathrm{Ni})$ to $\mathrm{Al}$ ratios show extremely high values relative to the so-called UPC values (McLennan, 2001, Table 2): The mean Ni/ Al ratio is six times higher than in UPC, seventy times higher for $\mathrm{Mo} / \mathrm{Al}$, and more than three hundreds times higher for $\mathrm{Cd} / \mathrm{Al}$ (Table 2). Even the lowest element to $\mathrm{Al}$ ratios, which occur mainly in Unit II, are higher than the corresponding value in UPC. The results indicate that significant parts of these elements are not related to the input of terrigenous minerals, but rather to in-situ biogenic and authigenic enrichments. The highest values for elemental ratios and enrichments in MD08 core occur within laminated intervals, and are even higher within sedimentary Unit III as compared to Unit I (Fig. 2). 


\section{Discussion}

A previous study of the MD08 core revealed the strong link between productivity in surface waters and OMZ variability during the last glacial period (MIS2 and 3), in relation to changes in atmospheric circulation over Baja California driven by Northern Hemisphere high latitude climate variability (Cartapanis et al., 2011). High productivity may have led to reduced bottom water oxygenation at site MD08 during interstadials. Changes in the wind patterns were proposed as mechanisms for changes in the strength, duration, and frequency of upwelling events, leading to higher productivity during interstadials events of MIS3. Higher bottom water oxygenation during Heinrich events was suggested to be produced by changes in oxygen advection by NPIW, formed in the northern Pacific. In light of the new datasets on MD08 core, that now cover the past $120 \mathrm{ka}$, we will focus our discussion on the oceanic and climatic millennial scale variability of the last interglacial period (MIS5).

\subsection{Millennial-scale productivity variations during MIS5}

The high-resolution records of opal, terrigenous, and carbonate fractions in the MD08 core display striking similarities with the NGRIP $\delta^{18} \mathrm{O}$ record on millennial timescales across the last interglacial period, despite limited age constraint earlier than $60 \mathrm{ka}$ (Fig. 2). The MD08 record shows higher opal content within laminated intervals that likely correspond to DO interstades 25 to 19 (Figs. 2 and 4). The opal content is extremely high during interstadials 25 to 21 (more than $40 \%$ ), while this enrichment is attenuated for interstades 20 and 19 (Fig. 4). In contrast, TOC remains rather stable during interstadials 25 to 21 (around $8 \%$ ), and increases up to $12 \%$ for interstades 20 and 19 (Fig. 2). Carbonate and terrigenous fractions show low values during Greenland interstades 25 to 19 , most likely due to dilution by opal and TOC as well as carbonate dissolution (Figs. 2 and 3).

We roughly estimated opal mass accumulation rate using gamma density obtained on board (Beaufort et al., 2002) and a constant sedimentation rate from 59.1 to $117 \mathrm{ka}$ (Table 1) to examine whether temporal variation of opal accumulation rate is different from that of opal concentration. The maximum range of wet bulk density is 1.1 to $1.8 \mathrm{~g} \mathrm{~cm}^{-3}$ for core MD08, which is much smaller than the change of opal content from several $\%$ to nearly $50 \%$ during MIS5. Consequently, the opal concentration and opal accumulation rates have very similar variability during MIS5.

The increase of opal concentration in bulk sediments could be produced by decline of carbonates and terrigenous fractions. If the dilution effect were the main cause of opal concentration changes, the sedimentation rate of high opal periods would be lower than for periods of low opal content. Alternatively, since we assume a constant sedimentation rate from 117 to $59.1 \mathrm{ka}$ (Table 1), the periods of high opal con- centration should be systematically shorter than interstadials of NGRIP record. Nonetheless, such a trend is not found in the records (Fig. 4). Consequently, opal variations reflect at least partly changes in the opal flux to the sea floor and/or the preservation of this component in sediments.

Both $\mathrm{Cd} / \mathrm{Al}$ and $\mathrm{Ni} / \mathrm{Al}$, closely related to biogenic productivity of surface waters (Nameroff et al., 2002), show increased values within laminated intervals. Elemental ratios $\left(\mathrm{Cd} / \mathrm{Al}, \mathrm{Ni} / \mathrm{Al}\right.$ and biogenic $\mathrm{Si}$ to organic carbon, $\mathrm{Si}_{\text {bio }} / \mathrm{C}$, Sect. 5.2, and Figs. 2 and 5) that are not affected by dilution, display similar variability to opal content, further suggesting that opal content reflects changes in the productivity. In summary, marine organic matter, opal, $\mathrm{Cd} / \mathrm{Al}$, and $\mathrm{Ni} / \mathrm{Al}$ variations suggest higher productivity during the intervals corresponding to Greenland warm DO interstadials of MIS5 (Fig. 4). This observation is consistent with the occurrence of upwelling-related diatom blooms in the laminated intervals of MD08 (Murdmaa et al., 2010).

The good match between productivity and oxygenations at MD08 with Greenland temperature records (Figs. 2 and 3 ) suggest strong connections between Northern Hemisphere high latitude climate and northeastern Pacific OMZ on the millennial-scale during MIS5 via atmospheric and/or oceanic pathways. In the following section, we discuss possible processes responsible for high opal content during MIS5 interstadials compared to Holocene and MIS3 interstadials.

\subsection{Atmospheric circulation impact on productivity}

Despite different climatic settings, high latitude cold Northern Hemisphere intervals (MIS2 and MIS4 as well as stadials of MIS3 and MIS5) were generally less productive than warmer interglacial and DO interstadial periods at site MD08. Considering that modern productivity over site MD08 is driven by wind, changes in local wind fields may have influenced productivity during MIS5 (Fig. 4). During cold events simulated by fresh water perturbation under pre-industrial conditions, low temperatures in the northern Pacific enhance the Aleutian Low (Mikolajewicz et al., 1997; Okumura et al., 2009). Cold temperatures over the North American continent favour the establishment of anticyclonic circulation (Kutzbach and Wright Jr., 1985; Romanova et al., 2006). These mechanisms could have reduced the southward wind intensity over the studied site during MIS5 stadials. Substantial millennial-scale changes in the volume, surface extent, and height of the North American ice sheet suggested by high amplitude sea level changes (Fig. 5) (Lambeck and Chappell, 2001; Siddall et al., 2007; Grant et al., 2012; Medina-Elizalde, 2013), could have been responsible for variations in atmospheric circulation (Romanova et al., 2006).

Continental records indicate millennial-scale variability in atmospheric circulation over the North American continent during MIS5. A multiproxy study in Lake Owens (southeastern California) suggests reduced rainfall and/or warmer 


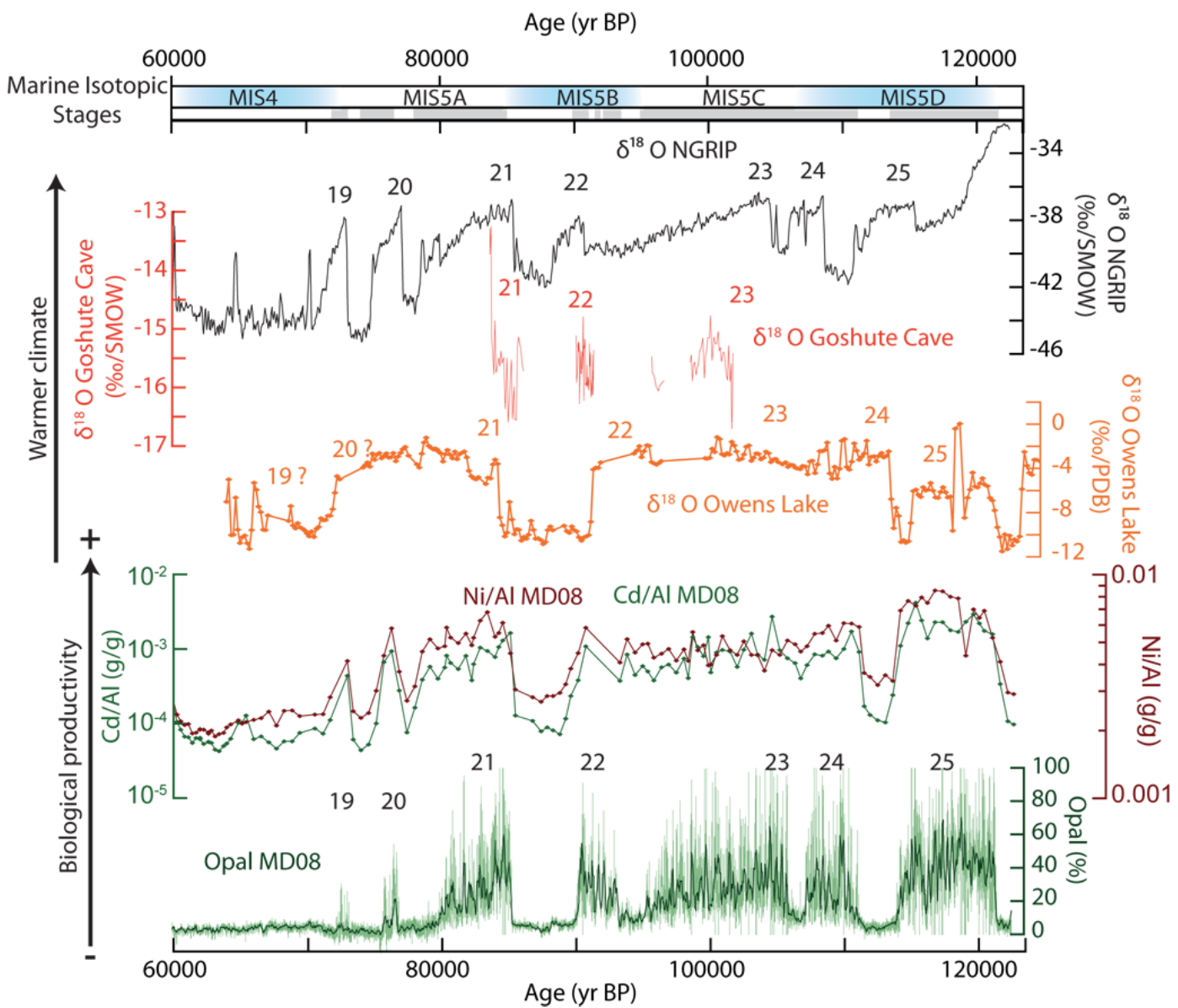

Fig. 4. The isotopic composition of NGRIP ice core ( $\delta^{18} \mathrm{O} \%$ o/SMOW) (NGRIP Members, 2004) ; the isotopic composition of Owens Lake sediment $\left(\delta^{18} \mathrm{O} \%\right.$ o/PDB) (Li et al., 2004), the isotopic composition of Goshute cave stalagmite $\left(\delta^{18} \mathrm{O} \%\right.$ o/PDB) (Denniston et al., 2007); and the opal content, $\mathrm{Cd} / \mathrm{Al}$, and $\mathrm{Ni} / \mathrm{Al}$ in MD02-2508 core.

conditions during interstadial events of MIS5 (e.g. $\delta^{18} \mathrm{O}$ of Owens Lake sediment, Figs. 1 and 4, (Li et al., 2004)), consistent with variations of isotopic composition of Goshute cave stalagmite (NE Nevada, (Denniston et al., 2007), Figs. 1 and 4). Previous studies in the southwestern United States over the last glacial interpreted millennial-scale speleothem $\delta^{18} \mathrm{O}$ variations to reflect latitudinal migrations of storm tracks and rainfall associated to the Polar Jet Stream and the ITCZ, implying atmospheric circulation changes, at least, in the Northern Hemisphere (Asmerom et al., 2010; Wagner et al., 2010). During warm interstadials, both polar jet and Northern Hemisphere summer ITCZ were proposed to have shifted northward (Asmerom et al., 2010; Wagner et al., 2010; Wang et al., 2012). By affecting upwelling intensity, duration or frequency, this atmospheric circulation change may have triggered productivity variability at MD08 (Cartapanis et al., 2011), as well as in the Panama Basin (Romero et al., 2011a; Cartapanis et al., 2012). Based on the fact that millennial-scale ITCZ latitudinal shifts existed during MIS5a
(Peterson et al., 2000), we infer the similar processes could have operated over the whole MIS5.

\subsection{Oceanic circulation impact on oxygenation and productivity}

High Mo / Al during MIS5 interstadials suggest reduced oxygenation of bottom water (Figs. 2 and 5). The high correlation between $\mathrm{Mn}$ and terrigenous element content $\left(R^{2}=0.97\right.$ between $\mathrm{Mn}$ and Ti) indicates that $\mathrm{Mn}$ oxides were dissolved in the sediment, and that bottom waters had never been oxic, even during stadial events (not shown). Changes in oceanic circulation could have impacted the OMZ dynamic by changing ventilation. Modelling studies indicate that reduction of North Atlantic Deep Water formation during Heinrich events and associated global oceanic circulation modifications could have increased the NPIW formation (Saenko et al., 2004; Timmermann et al., 2005; Schmittner et al., 2007; Okazaki et al., 2010), which was confirmed by observational studies for the last glacial period (Okazaki et al., 2010; Cartapanis et al., 2011; Rella et al., 2012). Oceanic circulation 


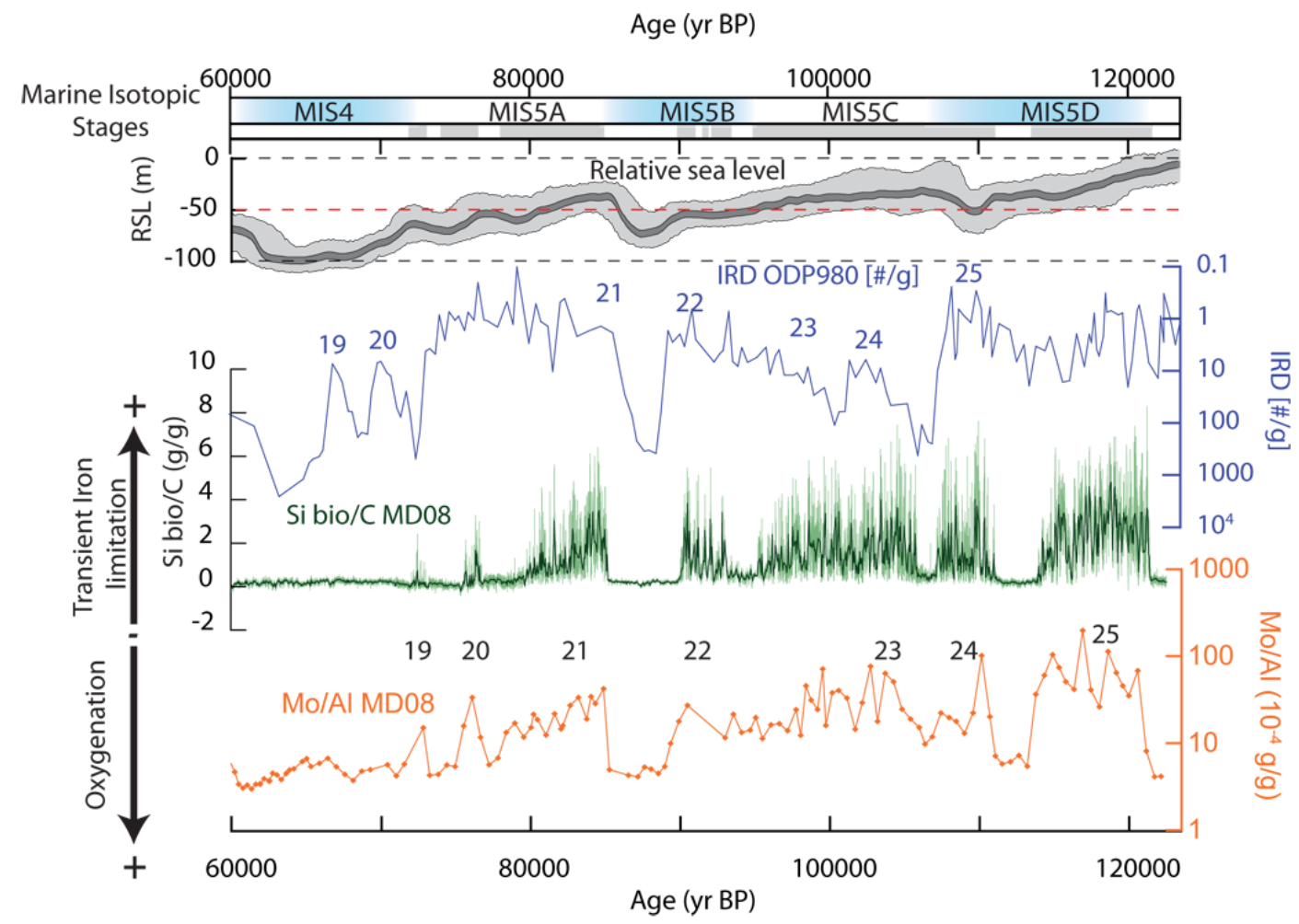

Fig. 5. The global relative sea level (Grant et al., 2012). Confidence interval of $95 \%$ (light grey) and probability maximum (dark grey) are indicated. The $50 \mathrm{~m}$ depth below modern sea level, corresponding to modern Bering Strait depth is highlighted in red. The Ice Rafted Debris content in North Atlantic ODP site 980 core plotted on an inverse logarithmic scale (Oppo et al., 2006), and the biogenic Si to C ratio $\left(\mathrm{Si}_{\mathrm{bio}} / \mathrm{C}\right)$ and $\mathrm{Mo} / \mathrm{Al}$ in MD02-2508 core.

variations could have modified the nutrient content of the upwelled water over site MD08, affecting biological productivity and oxygen consumption in the OMZ (Schmittner, 2005; Schmittner et al., 2007). Considering that Heinrichlike events probably occurred during the MIS5 (Fig. 5) (McManus et al., 1994; Eynaud et al., 2000; Oppo et al., 2006), changes in the ventilation and/or the nutrient inventory at Baja California cannot be ruled out. Numerical simulations evaluated the relative impact of productivity and ventilation on oxygen level in the Pacific during a simulated HE. It was shown that oxygenation changes at high latitude in the northern Pacific during HE were mainly driven by the advection of oxygen through NPIW (Schmittner et al., 2007). In contrast, at low latitudes in the Pacific, the change in biological productivity, related to the reduction of the upwelling of deep nutrient rich water was the main factor for the increased oxygenation of the intermediate water (Schmittner et al., 2007). MD08 site is situated at $23^{\circ} \mathrm{N}$, close to the modern NPIW southern limit, such as both oxygen advection and consumption could play a role in regulating the local intermediate depth oxygenation.

Silicic acid and nitrate inventory in subsurface waters of the northern Pacific is partly related to the upward advection of nutrient-rich Pacific Deep Water toward NPIW at high northern latitudes (Sarmiento et al., 2004). The enhanced NPIW formation during HE and stadials related to oceanic circulation changes (Saenko et al., 2004; Timmermann et al., 2005; Schmittner et al., 2007; Okazaki et al., 2010), possibly reduced the upward advection of deep, old, oxygen poor and nutrient rich water toward NPIW (Sarmiento et al., 2004; Rella et al., 2012). Considering that NPIW is probably the source for upwelling water in the northeastern Pacific (van Geen and Husby, 1996), stronger NPIW production could have lowered the productivity at site MD08, reduced oxygen consumption in NPIW, and enhanced oxygen advection toward the OMZ. This scenario would explain the correlation between productivity and bottom water oxygenation proxies (Fig. 5) along the NE Pacific margin as both oxygen advection and productivity (thus oxygen consumption) would have been related to NPIW formation. Alternatively, atmospheric connections (Harada et al., 2006; Clement and Peterson, 2008) altered surface hydrological conditions in NPIW formation zones (such as Okhotsk and Bering Seas), which affected the NPIW formation and/or oxygenation (Sarmiento et al., 2004; Schmittner et al., 2007; Rella et al., 2012), and thus the ventilation and/or the nutrient availability at MD08 core site during stadials/interstadials and HE. 
A fundamental difference in oceanic circulation conditions between the MIS5 and the last glacial period is related to sea level, which affected the communication between the Arctic Ocean and the northern Pacific through the Bering Strait (De Boer and Nof, 2004). Modelling studies indicate that the impact of Heinrich-like events on oceanic circulation over both northern Atlantic and Pacific oceans might have been reduced during interglacial periods (De Boer and Nof, 2004; Hu et al., 2012). During sea level high stands, any increase of the freshwater inputs in the northern Atlantic was partially diverted toward the northern Pacific through the still open Bering Strait, thus weakening the impact of HE on the North Atlantic Deep Water (De Boer and Nof, 2004; Hu et al., 2012). At the same time, freshwater influx into the northern Pacific probably reduced NPIW formation. Moreover, global reorganization of oceanic circulation, that favoured NPIW formation during glacial age HEs (Saenko et al., 2004; Timmermann et al., 2005), would have been weakened during MIS5. Consequently, Heinrich-like events during MIS5 should have had reduced impact on the northeastern Pacific OMZ as compared to glacial periods. In spite of this, no obvious differences in millennial-scale response of redox sensitive trace elements for glacial and interglacial periods in our records are seen (Fig. 2). This suggests that productivity is the main factor controlling millennial-scale variations of the bottom water oxygenation at core MD08 site throughout the MIS5. Productivity changes could have been related to either atmospheric or oceanic processes. This scenario, however, depends on the sea level changes during MIS5 stadial/Heinrich-like events. The present depth of the Bering Strait is around $50 \mathrm{~m}$, close to the reconstructed (Fig. 5) and simulated sea level during MIS5 (Lambeck et al., 2002; Waelbroeck et al., 2002; Cutler et al., 2003; Hu et al., 2010; Grant et al., 2012). This suggests that Arctic/Pacific water exchanges were probably limited like the present state. In order to address the Bering Strait influence on the past North Pacific climate and oceanic circulation, and furthermore, the global climate and oceanic circulation variations on both glacial/interglacial and millennial timescales (Okumura et al., 2009; Hu et al., 2012), it will be necessary to develop a well dated record of the opening and closure of the Bering Strait.

\subsection{High biogenic opal content in MIS5 sediments}

One of the most striking features of the $120 \mathrm{ka}$ MD08 record is the extraordinary high opal content during the MIS5 (Fig. 2). The sediment deposited during MIS5 interstadial events has been identified as diatom-rich laminated sediment (Murdmaa et al., 2010). The formation of this type of sediment structure may occur during major diatom blooms within active frontal zones, which favor the aggregation of diatoms and the rapid sinking of frustules downward (Kemp et al., 1996; Shimada et al., 2008; Romero et al., 2011b). Changes in the seasonal and latitudinal insolation pattern during MIS5 as compared to the Holocene could be responsible for changes in the atmospheric circulation (MonteroSerrano et al., 2011; Herold et al., 2012), wind driven upwelling, and productivity. However, high opal production extends at least over $40 \mathrm{ka}(120-80 \mathrm{ka})$, during periods of different changes in the intensity and the latitudinal distribution of insolation. This suggests that insolation variation was not likely responsible for the buildup of mat deposits in Baja California.

Since site MD08 is located south of the modern limit of Subarctic Water transported by the California Current, the southward extension of the latter toward site MD08 (ca. $23^{\circ} \mathrm{N}$ ) might have contributed to the build-up of diatomrich laminations during MIS5. The nearby site NH15P (ca. $22^{\circ} \mathrm{N}, 106^{\circ} \mathrm{W}, 420 \mathrm{~m}$ water depth, Fig. 1 Ganeshram and Pedersen, 1998) shows similar variability in opal content with increased values during interglacial periods. It is worth of noting that there is no obvious difference between Holocene and MIS5 opal content at site NH15P, which is consistent with the hypothesis that the southern limit of California Current was situated above MD08 during MIS5 whereas site NH15P was beyond of the influence of California Current for both MIS5 and Holocene.

Despite the fact that nitrate availability was thought to be the limiting factor for diatom production in surface waters overlying MD08 (Moore et al., 2004), shipboard seawater incubation experiments demonstrated that diatom production within upwelling zones along California margins was rather limited by iron (Hutchins and Bruland, 1998; Firme et al., 2003; Moore et al., 2013). Intense productivity could have led to total Fe utilisation during upwelling events thus to transient $\mathrm{Fe}$ limitation at the end of an upwelling event (Hutchins and Bruland, 1998; Firme et al., 2003). Iron limitation can lead to reduced cellular organic matter production and increased silicification (high cellular $\mathrm{Si}: \mathrm{C}$ and $\mathrm{Si} / \mathrm{N}$ ratio) of diatoms (Baines et al., 2010, 2011; Brzezinski et al., 2011), high Si:C ratio in sinking biogenic particles, high opal flux (Hutchins and Bruland, 1998; Firme et al., 2003; Pichevin et al., 2012), and better frustule preservation in sediments. This scenario is consistent with the unvarying TOC contents in MD08 core across stadial/interstadials DO intervals of MIS5 (Fig. 2), and high biogenic $\mathrm{Si}$ to $\mathrm{C}$ ratio $\left(\mathrm{Si}_{\text {bio }} / \mathrm{C}\right.$, Fig. 5). Moreover, terrigenous element content during MIS5 is low in MD08 core, possibly because of reduced aeolian and fluvial inputs, suggesting decreased iron inputs to the surface waters. Dissolved Fe in upwelling areas also depends on interactions between upwelled waters and underlying shelf sediments (Elrod et al., 2004; Bruland et al., 2005), such as reduced $\mathrm{Fe}$ content in the sediment could have further enhanced Fe depletion in upwelled waters.

As suggested by (Romero et al., 2011b), change in nutrient availability and supply in the photic zone might have affected the buildup of diatoms mats deposits. In this scenario, changes in the intensity of processes described in Sect. 5.2 (wind driven upwelling) and Sect. 5.3 (oceanic circulation 
impact on nutrient availability) between Holocene and MIS5 could be responsible for higher diatom productivity during MIS5.

Regardless of the mechanism responsible (California Current position, nutrient inventory at subsurface or nutrient supply to the photic zone), we suggest that the climatic/oceanic setting might have led to high opal production during MIS5. Global ice volume (Lambeck et al., 2002; Waelbroeck et al., 2002; Cutler et al., 2003; Hu et al., 2010; Grant et al., 2012) suggests the existence of a small ice sheet over the North American continent during MIS5d to MIS5a (Bonelli et al., 2009; Ganopolski et al., 2010). Leaving aside millennialscale variability, the presence of this ice sheet (absent during the Holocene and MIS5e) could have been responsible for high MIS5 opal content in MD08 as compared to Holocene, by either modifying local wind stress, California Current extension, or nutrient content of upwelling waters. In order to determine whether these specific features (higher opal during MIS5 than during Holocene) reflect regional or global processes rather than a local non-linear response to climatic variations, more records in upwelling zones of northeastern Pacific for the MIS5 are required.

\section{Conclusions}

We studied core MD02-2508, retrieved off the Baja California margin, at present northern limit of the northeastern $\mathrm{Pa}$ cific Oxygen Minimum Zone (OMZ), using high resolution $\mathrm{XRF}$ measurements ( $\mathrm{Si} / \mathrm{Ti}$ as a biogenic opal indicator, $\mathrm{Ca}$ as a biogenic carbonate indicator, $\mathrm{Br}$ as a marine organic carbon indicator, and $\mathrm{Ti}$ as a terrigenous fraction indicator) and ICP-MS trace elements measurements (Mo, Ni, Cd), for the last interglacial period (MIS5). The data allowed us to better constrain the millennial scale variability of past biological productivity and oxygenation at the core site over the studied period.

Opal, $\mathrm{Ni} / \mathrm{Al}$, and $\mathrm{Cd} / \mathrm{Al}$ increased during the DO interstadial events identified in Greenland ice cores over the MIS5, strongly suggesting an increase in biological productivity. A high $\mathrm{Mo} / \mathrm{Al}$ ratio within interstadials events indicates that the OMZ strengthened during these intervals.

Despite differences in the climatic and oceanic conditions, productivity and oxygenation during MIS5 displayed millennial-scale variability in relation to high northern latitude climates that are comparable to those over the last glacial period. Enhanced communication between the $\mathrm{Pa}$ cific and Arctic Oceans during MIS5 due to higher sea level does not seem to have strongly modified the productivity and bottom water ventilation response. This suggests that atmospheric teleconnection was the major link between the mid-latitude productivity and ventilation variations, and the high latitude Northern Hemisphere climate. Changes in atmospheric circulation, such as latitudinal shift of the polar jet stream, the storm track, and the ITCZ location during DO-
$\mathrm{H}$ events of the past $120 \mathrm{ka}$ probably affected wind driven upwelling and hence biological productivity. Alternatively, changes in the oceanic circulation could have modified productivity via changes in the deep upwelling of nutrient rich water, if this process was not affected by changes in ArcticPacific communication through the Bering strait.

Oxygenation variations at the core site were more likely related to changes in the biological productivity, but also possibly to changes of North Pacific Intermediate Water production because of atmospheric changes at Northern Hemisphere high latitudes in the Pacific, that affected oxygen inputs and nutrient availability in subsurface waters.

While several mechanisms (changes in California Current southward extension, modification of nutrient availability in surface water through changes of atmospheric and oceanic circulation) could explain the high opal content and $\mathrm{Si} / \mathrm{C}$ during MIS5, we suggest that the presence of an ice sheet over the northern part of northern America was probably indirectly involved in the build up of diatom ooze deposits at the Baja California.

Acknowledgements. We thank Luc Beaufort (chief scientist), Yvon Balut (IPEV), and the team of the IMAGESVIII-MONA cruise (MD126 North American Margin) on board of Marion Dufresne. We also thank Marta Garcia for technical assistance with ICP-MS measurements, Frauke Rostek for additional TOC measurements, Genevieve Elsworth for English polishing, Eric Galbraith for discussion and support, and A. Schmittner and L. Pichevin for constructive comments during the review of the manuscript. We are grateful to MESR, the Collège de France and McGill University for providing salary support to O. Cartapanis. Paleoclimate work at CEREGE is supported by grants from the Collège de France, the Comer Science and Education Foundation, the CNRS (LEFE-EVE MISLOLA), and the European Community (Project Past4Future).

Edited by: E. Brook

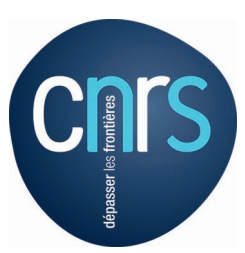

The publication of this article is financed by CNRS-INSU.

\section{References}

Altabet, M. A., Higginson, M. J., and Murray, D. W.: The effect of millennial-scale changes in Arabian Sea denitrification on atmospheric $\mathrm{CO}_{2}$, Nature, 415, 159-162, 2002.

Arellano-Torres, E., Pichevin, L. E., and Ganeshram, R. S.: Highresolution opal records from the eastern tropical Pacific provide evidence for silicic acid leakage from HNLC regions during glacial periods, Quaternary Sci. Rev., 30, 1112-1121, 2011.

Asmerom, Y., Polyak, V. J., and Burns, S. J.: Variable winter moisture in the southwestern United States linked to rapid glacial climate shifts, Nat. Geosci., 3, 114-117, 2010. 
Auad, G., Roemmich, D., and Gilson, J.: The California Current System in relation to the Northeast Pacific Ocean circulation, Prog. Oceanogr., 91, 576-592, 2011.

Baines, S. B., Twining, B. S., Brzezinski, M. A., Nelson, D. M., and Fisher, N. S.: Causes and biogeochemical implications of regional differences in silicification of marine diatoms, Global Biogeochem. Cy., 24, GB4031, doi:10.1029/2010GB003856, 2010.

Baines, S. B., Twining, B. S., Vogt, S., Balch, W. M., Fisher, N. S., and Nelson, D. M.: Elemental composition of equatorial Pacific diatoms exposed to additions of silicic acid and iron, Deep Sea Res. II, 58, 512-523, doi:10.1016/j.dsr2.2010.08.003, 2011.

Beaufort, L. et al. (Members of the scientific party): MD126IMAGES VIII Marges Ouest Nord Américaines MONA Cruise Report, Institut Paul Emile Victor, Plouzané, France, 2002.

Blanchet, C. L., Thouveny, N., Vidal, L., Leduc, G., Tachikawa, K., Bard, E., and Beaufort, L.: Terrigenous input response to glacial/interglacial climatic variations over southern Baja California: a rock magnetic approach, Quaternary Sci. Rev., 26, 3118-3133, 2007.

Bonelli, S., Charbit, S., Kageyama, M., Woillez, M.-N., Ramstein, G., Dumas, C., and Quiquet, A.: Investigating the evolution of major Northern Hemisphere ice sheets during the last glacialinterglacial cycle, Clim. Past, 5, 329-345, doi:10.5194/cp-5-3292009, 2009.

Bostock, H. C., Opdyke, B. N., and Williams, M. J. M.: Characterising the intermediate depth waters of the Pacific Ocean using [delta]13C and other geochemical tracers, Deep-Sea Res. I, 57, 847-859, doi:10.1016/j.dsr.2010.04.005, 2010.

Bruland, K. W., Rue, E. L., Smith, G. J., and DiTullio, G. R.: Iron, macronutrients and diatom blooms in the Peru upwelling regime: brown and blue waters of Peru, Mar. Chem., 93, 81-103, doi:10.1016/j.marchem.2004.06.011, 2005.

Brzezinski, M. A., Baines, S. B., Balch, W. M., Beucher, C. P., Chai, F., Dugdale, R. C., Krause, J. W., Landry, M. R., Marchi, A., Measures, C. I., Nelson, D. M., Parker, A. E., Poulton, A. J., Selph, K. E., Strutton, P. G., Taylor, A. G., and Twining, B. S.: Co-limitation of diatoms by iron and silicic acid in the equatorial Pacific, Deep Sea Res. II, 58, 493-511, doi:10.1016/j.dsr2.2010.08.005, 2011.

Cartapanis, O., Tachikawa, K., and Bard, E.: Northeastern Pacific oxygen minimum zone variability over the past $70 \mathrm{kyr}$ : Impact of biological production and oceanic ventilation, Paleoceanography, 26, PA4208, doi:10.1029/2011pa002126, 2011.

Cartapanis, O., Tachikawa, K., and Bard, E.: Latitudinal variations in intermediate depth ventilation and biological production over northeastern Pacific Oxygen Minimum Zones during the last 60ka, Quaternary Sci. Rev., 53, 24-38, 2012.

Clement, A. C. and Peterson, L. C.: Mechanisms of abrupt climate change of the last glacial period, Rev. Geophys., 46, 39, Rg4002, doi:10.1029/2006rg000204, 2008.

Croudace, I. W., Rindby, A., and Rothwell, R. G.: ITRAX: description and evaluation of a new multi-function X-ray core scanner, New Techniques in Sediment Core Analysis, Geological Society, London, Special Publications, 267, 51-63, 2006.

Cutler, K. B., Edwards, R. L., Taylor, F. W., Cheng, H., Adkins, J., Gallup, C. D., Cutler, P. M., Burr, G. S., and Bloom, A. L.: Rapid sea-level fall and deep-ocean temperature change since the last interglacial period, Earth. Planet. Sci. Lett., 206, 253-271, doi:10.1016/S0012-821X(02)01107-X, 2003.
De Boer, A. M. and Nof, D.: The Bering Strait's grip on the northern hemisphere climate, Deep-Sea Res. I, 51, 1347-1366, 2004.

Dean, W. E.: Sediment geochemical records of productivity and oxygen depletion along the margin of western North America during the past 60,000 years: teleconnections with Greenland Ice and the Cariaco Basin, Quaternary Sci. Rev., 26, 98-114, doi:10.1016/j.quascirev.2006.08.006, 2007.

Dean, W. E., Zheng, Y., Ortiz, J. D., and van Geen, A.: Sediment Cd and Mo accumulation in the oxygen-minimum zone off western Baja California linked to global climate over the past $52 \mathrm{kyr}$, Paleoceanography, 21, PA4209, doi:10.1029/2005pa001239, 2006.

DeMaster, D. J.: The supply and accumulation of silica in the marine environment, Geochim. Cosmochim. Acta, 45, 1715-1732, doi:10.1016/0016-7037(81)90006-5, 1981.

Denniston, R. F., Asmerom, Y., Polyak, V., Dorale, J. A., Carpenter, S. J., Trodick, C., Hoye, B., and Gonzalez, L. A.: Synchronous millennial-scale climatic changes in the Great Basin and the North Atlantic during the last interglacial, Geology, 35, 619-622, doi:10.1130/g23445a.1, 2007.

Dubois, N., Kienast, M., Kienast, S., Calvert, S. E., Francois, R., and Anderson, R. F.: Sedimentary opal records in the eastern equatorial Pacific: It is not all about leakage, Global Biogeochem. Cy., 24, GB4020, doi:10.1029/2010gb003821, 2010.

Dubois, N., Kienast, M., Kienast, M., Normandeau, C., Calvert, S. E., Herbert, T. D., and Mix, A. C.: Millennial-scale variations in hydrography and biogeochemistry in the Eastern Equatorial Pacific over the last 100 kyr, Quaternary Sci. Rev., 30, 210-223, 2011.

Elrod, V. A., Berelson, W. M., Coale, K. H., and Johnson, K S.: The flux of iron from continental shelf sediments: A missing source for global budgets, Geophys. Res. Lett., 31, L12307, doi:10.1029/2004GL020216, 2004

Eynaud, F., Turon, J. L., Sanchez-Goni, M. F., and Gendreau, S.: Dinoflagellate cyst evidence of Heinrich-like events off Portugal during the Marine Isotopic Stage 5, Mar. Micropaleontol., 40, 9-21, 2000.

Firme, G. F., Rue, E. L., Weeks, D. A., Bruland, K. W., and Hutchins, D. A.: Spatial and temporal variability in phytoplankton iron limitation along the California coast and consequences for Si, N, and C biogeochemistry, Global Biogeochem. Cy., 17, 1016, doi:10.1029/2001GB001824, 2003.

Galbraith, E. D., Kienast, M., Pedersen, T. F., and Calvert, S. E.: Glacial-interglacial modulation of the marine nitrogen cycle by high-latitude O-2 supply to the global thermocline, Paleoceanography, 19, PA4007, doi:10.1029/2003pa001000, 2004.

Ganeshram, R. S. and Pedersen, T. F.: Glacial-interglacial variability in upwelling and bioproductivity off NW Mexico: Implications for quaternary paleoclimate, Paleoceanography, 13, 634645, 1998.

Ganopolski, A., Calov, R., and Claussen, M.: Simulation of the last glacial cycle with a coupled climate ice-sheet model of intermediate complexity, Clim. Past, 6, 229-244, doi:10.5194/cp-6-2292010, 2010.

Garcia, H. E., Locarnini, R. A., Boyer, T. P., Antonov, J. I., Baranova, O. K., Zweng, M. M., and Johnson, D. R.: World Ocean Atlas 2009, Volume 3: Dissolved Oxygen, Apparent Oxygen Utilization, and Oxygen Saturation. S. Levitus, (Ed.) NOAA Atlas NESDIS 70, U.S. Government Printing Office, Washington, D.C., 344 pp., 2010. 
Grant, K. M., Rohling, E. J., Bar-Matthews, M., Ayalon, A., Medina-Elizalde, M., Ramsey, C. B., Satow, C., and Roberts, A. P.: Rapid coupling between ice volume and polar temperature over the past 150,000 years, Nature, 491, 744-747, doi:10.1038/nature11593, 2012.

Harada, N., Ahagon, N., Sakamoto, T., Uchida, M., Ikehara, M., and Shibata, Y.: Rapid fluctuation of alkenone temperature in the southwestern Okhotsk Sea during the past $120 \mathrm{ky}$, Global Planet. Change, 53, 29-46, 2006.

Hendy, I. L.: The paleoclimatic response of the Southern Californian Margin to the rapid climate change of the last 60 ka: A regional overview, Quaternerary Int., 215, 62-73, doi:10.1016/j.quaint.2009.06.009, 2010.

Hendy, I. L. and Kennett, J. P.: Dansgaard-Oeschger cycles and the California Current System: Planktonic foraminiferal response to rapid climate change in Santa Barbara Basin, Ocean Drilling Program hole 893A, Paleoceanography, 15, 30-42, 2000.

Hendy, I. L. and Pedersen, T. F.: Is pore water oxygen content decoupled from productivity on the California Margin? Trace element results from Ocean Drilling Program Hole 1017E, San Lucia slope, California, Paleoceanography, 20, PA4026, doi:10.1029/2004pa001123, 2005.

Hendy, I. L., Pedersen, T. F., Kennett, J. P., and Tada, R.: Intermittent existence of a southern Californian upwelling cell during submillennial climate change of the last $60 \mathrm{kyr}$, Paleoceanography, 19, PA3007, doi:10.1029/2003pa000965, 2004.

Herold, N., Yin, Q. Z., Karami, M. P., and Berger, A.: Modelling the climatic diversity of the warm interglacials, Quaternary Sci. Rev., 56, 126-141, doi:10.1016/j.quascirev.2012.08.020, 2012.

Hu, A., Meehl, G. A., Otto-Bliesner, B. L., Waelbroeck, C., Han, W., Loutre, M.-F., Lambeck, K., Mitrovica, J. X., and Rosenbloom, N.: Influence of Bering Strait flow and North Atlantic circulation on glacial sea-level changes, Nat. Geosci., 3, 118-121, doi:10.1038/ngeo729, 2010.

Hu, A., Meehl, G. A., Han, W., Abe-Ouchi, A., Morrill, C., Okazaki, Y., and Chikamoto, M. O.: The Pacific-Atlantic seesaw and the Bering Strait, Geophys. Res. Lett., 39, L03702, doi:10.1029/2011g1050567, 2012.

Hutchins, D. A. and Bruland, K. W.: Iron-limited diatom growth and Si:N uptake ratios in a coastal upwelling regime, Nature, 393, 561-564, 1998.

Johnsen, S. J., Dahl-Jensen, D., Gundestrup, N., Steffensen, J. P., Clausen, H. B., Miller, H., Masson-Delmotte, V., Sveinbjörnsdottir, A. E., and White, J.: Oxygen isotope and palaeotemperature records from six Greenland ice-core stations: Camp Century, Dye-3, GRIP, GISP2, Renland and NorthGRIP, J. Quaternary Sci., 16, 299-307, 2001.

Karstensen, J., Stramma, L., and Visbeck, M.: Oxygen minimum zones in the eastern tropical Atlantic and Pacific oceans, Prog. Oceanogr., 77, 331-350, doi:10.1016/j.pocean.2007.05.009, 2008.

Kemp, A. E. S., Baldauf, J. G., and Pearce, R. B.: Origins and palaeoceangraphic significance of laminated daitom ooze from the Eastern Equatorial Pacific Ocean, Geological Society, London, Special Publications, 116, 243-252, doi:10.1144/gsl.sp.1996.116.01.19, 1996.

Kienast, S. S., Calvert, S. E., and Pedersen, T. F.: Nitrogen isotope and productivity variations along the northeast Pacific margin over the last 120 kyr: Surface and subsurface paleoceanography, Paleoceanography, 17, doi:10.1029/2001pa000650, 2002.

Kienast, S. S., Kienast, M., Jaccard, S., Calvert, S. E., and Francois, R.: Testing the silica leakage hypothesis with sedimentary opal records from the eastern equatorial Pacific over the last 150 kyrs, Geophys. Res. Lett., 33, L15607, doi:10.1029/2006g1026651, 2006.

Kutzbach, J. E. and Wright Jr., H. E.: Simulation of the climate of 18,000 years BP: Results for the North American/North Atlantic/European sector and comparison with the geologic record of North America, Quaternary Sci. Rev., 4, 147-187, 1985.

Lambeck, K. and Chappell, J.: Sea level change through the last glacial cycle, Science, 292, 679-686, 2001.

Lambeck, K., Esat, T. M., and Potter, E.-K.: Links between climate and sea levels for the past three million years, Nature, 419, 199206, 2002.

Leduc, G.: Temporal variations of hydrological changes in the eastern pacific. Geochemical, isotopic and micropaleontological approaches, Ph-D, Aix-Marseille III, 2007.

Li, H.-C., Bischoff, J. L., Ku, T.-L., and Zhu, Z.-Y.: Climate and hydrology of the Last Interglaciation (MIS 5) in Owens Basin, California: isotopic and geochemical evidence from core OL-92, Quaternary Sci. Rev., 23, 49-63, 2004.

Lynn, R. J. and Simpson, J. J.: The California Current System: The Seasonal Variability of its Physical Characteristics, J. Geophys. Res., 92, 12947-12966, doi:10.1029/JC092iC12p12947, 1987.

Marchitto, T. M., Lehman, S. J., Ortiz, J. D., Fluckiger, J., and van Geen, A.: Marine radiocarbon evidence for the mechanism of deglacial atmospheric $\mathrm{CO}_{2}$ rise, Science, 316, 1456-1459, doi:10.1126/science.1138679, 2007.

Mayer, L. M., Schick, L. L., Allison, M. A., Ruttenberg, K. C., and Bentley, S. J.: Marine vs. terrigenous organic matter in Louisiana coastal sediments: The uses of bromine:organic carbon ratios, Mar. Chem., 107, 244-254, 2007.

McLennan, S. M.: Relationships between the trace element composition of sedimentary rocks and upper continental crust, Geochem. Geophys. Geosyst., 2, 1021, doi:10.1029/2000GC000109, 2001.

McManus, J. F., Bond, G. C., Broecker, W. S., Johnsen, S., Labeyrie, L., and Higgins, S.: High-resolution climate records from the North Atlantic during the last interglacial, Nature, 371, 326-329, 1994.

Medina-Elizalde, M.: A global compilation of coral sea-level benchmarks: Implications and new challenges, Earth. Planet. Sci. Lett., 362, 310-318, doi:10.1016/j.epsl.2012.12.001, 2013.

Mikolajewicz, U., Crowley, T. J., Schiller, A., and Voss, R.: Modelling teleconnections between the North Atlantic and North Pacific during the Younger Dryas, Nature, 387, 384-387, 1997.

Montero-Serrano, J.-C., Bout-Roumazeilles, V., Carlson, A. E., Tribovillard, N., Bory, A., Meunier, G., Sionneau, T., Flower, B. P., Martinez, P., Billy, I., and Riboulleau, A.: Contrasting rainfall patterns over North America during the Holocene and Last Interglacial as recorded by sediments of the northern Gulf of Mexico, Geophys. Res. Lett., 38, L14709, doi:10.1029/2011g1048194, 2011. 
Moore, C. M., Mills, M. M., Arrigo, K. R., Berman-Frank, I., Bopp, L., Boyd, P. W., Galbraith, E. D., Geider, R. J., Guieu, C., Jaccard, S. L., Jickells, T. D., La Roche, J., Lenton, T. M., Mahowald, N. M., Maranon, E., Marinov, I., Moore, J. K., Nakatsuka, T., Oschlies, A., Saito, M. A., Thingstad, T. F., Tsuda, A., and Ulloa, O.: Processes and patterns of oceanic nutrient limitation, Nat. Geosci., 6, 701-710, doi:10.1038/ngeo1765, 2013.

Moore, J. K., Doney, S. C., and Lindsay, K.: Upper ocean ecosystem dynamics and iron cycling in a global threedimensional model, Global Biogeochem. Cy., 18, GB4028, doi:10.1029/2004gb002220, 2004.

Müller, P. J. and Schneider, R.: An automated leaching method for the determination of opal in sediments and particulate matter, Deep-Sea Res. Part I Oceanogr. Res. Pap., 40, 425-444, doi:10.1016/0967-0637(93)90140-X, 1993.

Murdmaa, I. O., Kazarina, G. H., Beaufort, L., Ivanova, E. V., Emelyanov, E. M., Kravtsov, V. A., Alekhina, G. N., and Vasileva, V. E.: Upper Quaternary Laminated Sapropelic Sediments from the Continental Slope of Baja California, Lithol. Mineral Resour., 45, 154-171, doi:10.1134/S0024490210020057, 2010.

Nameroff, T. J., Balistrieri, L. S., and Murray, J. W.: Suboxic trace metal geochemistry in the eastern tropical North Pacific, Geochim. Cosmochim. Acta, 66, 1139-1158, 2002.

Nameroff, T. J., Calvert, S. E., and Murray, J. W.: Glacialinterglacial variability in the eastern tropical North Pacific oxygen minimum zone recorded by redox-sensitive trace metals, $\mathrm{Pa}-$ leoceanography, 19, PA1010, doi:10.1029/2003pa000912, 2004.

NGRIP Members: High-resolution record of Northern Hemisphere climate extending into the last interglacial period, Nature, 431, 147-151, doi:10.1038/nature02805, 2004.

Okazaki, Y., Timmermann, A., Menviel, L., Harada, N., Abe-Ouchi, A., Chikamoto, M. O., Mouchet, A., and Asahi, H.: Deepwater Formation in the North Pacific During the Last Glacial Termination, Science, 329, 200-204, doi:10.1126/science.1190612, 2010.

Okumura, Y. M., Deser, C., Hu, A., Timmermann, A., and Xie, S. P.: North Pacific Climate Response to Freshwater Forcing in the Subarctic North Atlantic: Oceanic and Atmospheric Pathways, J. Climate, 22, 1424-1445, doi:10.1175/2008jcli2511.1, 2009.

Oppo, D. W., McManus, J. F., and Cullen, J. L.: Evolution and demise of the Last Interglacial warmth in the subpolar North Atlantic, Quaternary Sci. Rev., 25, 3268-3277, 2006.

Ortiz, J. D., O’Connell, S. B., DelViscio, J., Dean, W., Carriquiry, J. D., Marchitto, T., Zheng, Y., and van Geen, A.: Enhanced marine productivity off western North America during warm climate intervals of the past $52 \mathrm{ky}$, Geology, 32, 521-524, 2004.

Paulmier, A. and Ruiz-Pino, D.: Oxygen minimum zones (OMZs) in the modern ocean, Prog. Oceanogr., 80, 113-128, 2009.

Paulmier, A., Ruiz-Pino, D., and Garcon, V.: The oxygen minimum zone (OMZ) off Chile as intense source of $\mathrm{CO}_{2}$ and $\mathrm{N}_{2} \mathrm{O}$, Cont. Shelf Res., 28, 2746-2756, 2008.

Paulmier, A., Ruiz-Pino, D., and Garçon, V.: $\mathrm{CO}_{2}$ maximum in the oxygen minimum zone (OMZ), Biogeosciences, 8, 239-252, doi:10.5194/bg-8-239-2011, 2011.

Pennington, J. T., Mahoney, K. L., Kuwahara, V. S., Kolber, D. D., Calienes, R., and Chavez, F. P.: Primary production in the eastern tropical Pacific: A review, Prog. Oceanogr., 69, 285-317, 2006.
Peterson, L. C., Haug, G. H., Hughen, K. A., and Rohl, U.: Rapid changes in the hydrologic cycle of the tropical Atlantic during the last glacial, Science, 290, 1947-1951, 2000.

Pichevin, L., Bard, E., Martinez, P., and Billy, I.: Evidence of ventilation changes in the Arabian Sea during the late Quaternary: Implication for denitrification and nitrous oxide emission, Global Biogeochem. Cy., 21, GB4008, doi:10.1029/2006gb002852, 2007.

Pichevin, L., Ganeshram, R., Francavilla, S., Arellano-Torres, E., Pedersen, T., and Beaufort, L.: Interhemispheric leakage of isotopically heavy nitrate in the eastern tropical Pacific during the last glacial period, Paleoceanography, 25, 1204, doi:10.1029/2009pa001754, 2010.

Pichevin, L., Ganeshram, R. S., Reynolds, B. C., Prahl, F., Pedersen, T. F., Thunell, R., and McClymont, E. L.: Silicic acid biogeochemistry in the Gulf of California: Insights from sedimentary Si isotopes, Paleoceanography, 27, doi:10.1029/2011PA002237, 2012.

Rella, S. F., Tada, R., Nagashima, K., Ikehara, M., Itaki, T., Ohkushi, K. I., Sakamoto, T., Harada, N., and Uchida, M.: Abrupt changes of intermediate water properties on the northeastern slope of the Bering Sea during the last glacial and deglacial period, Paleoceanography, 27, PA3203, doi:10.1029/2011pa002205, 2012.

Romanova, V., Lohmann, G., Grosfeld, K., and Butzin, M.: The relative role of oceanic heat transport and orography on glacial climate, Quaternary Sci. Rev., 25, 832-845, 2006.

Romero, O. E., Leduc, G., Vidal, L., and Fischer, G.: Millennial variability and long-term changes of the diatom production in the eastern equatorial Pacific during the last glacial cycle, Paleoceanography, 26, PA2212, doi:10.1029/2010pa002099, 2011a.

Romero, O. E., Swann, G. E. A., Hodell, D. A., Helmke, P., Rey, D., and Rubio, B.: A highly productive Subarctic Atlantic during the Last Interglacial and the role of diatoms, Geology, 39, 10151018, doi:10.1130/g32454.1, 2011b.

Saenko, O. A., Schmittner, A., and Weaver, A. J.: The AtlanticPacific seesaw, J. Climate, 17, 2033-2038, 2004.

Sarmiento, J. L., Gruber, N., Brzezinski, M. A., and Dunne, J. P. High-latitude controls of thermocline nutrients and low latitude biological productivity, Nature, 479, 56-60, 2004.

Schmittner, A.: Decline of the marine ecosystem caused by a reduction in the Atlantic overturning circulation, Nature, 434, 628633, 2005.

Schmittner, A., Galbraith, E. D., Hostetler, S. W., Pedersen, T. F., and Zhang, R.: Large fluctuations of dissolved oxygen in the Indian and Pacific oceans during Dansgaard-Oeschger oscillations caused by variations of North Atlantic Deep Water subduction, Paleoceanography, 22, Pa3207 doi:10.1029/2006pa001384, 2007.

Shcherbina, A. Y., Talley, L. D., and Rudnick, D. L.: Direct observations of North Pacific ventilation: Brine rejection in the Okhotsk Sea, Science, 302, 1952-1955, 2003.

Shimada, C., Sato, T., Toyoshima, S., Yamasaki, M., and Tanimura, Y.: Paleoecological significance of laminated diatomaceous oozes during the middle-to-late Pleistocene, North Atlantic Ocean (IODP Site U1304), Mar. Micropaleontol., 69, 139-150, 2008. 
Siddall, M., Chappell, J., and Potter, E. K.: 7. Eustatic sea level during past interglacials, in: Developments in Quaternary Sciences, edited by: Frank Sirocko, M. C. M. F. S. G. and Thomas, L., Elsevier, 75-92, 2007.

Stramma, L., Johnson, G. C., Sprintall, J., and Mohrholz, V.: Expanding oxygen-minimum zones in the tropical oceans, Science, 320, 655-658, doi:10.1126/science.1153847, 2008.

Stramma, L., Johnson, G. C., Firing, E., and Schmidtko, S.: Eastern Pacific oxygen minimum zones: Supply paths and multidecadal changes, J. Geophys. Res.-Ocean., 115, C09011, doi:10.1029/2009jc005976, 2010a.

Stramma, L., Schmidtko, S., Levin, L. A., and Johnson, G. C.: Ocean oxygen minima expansions and their biological impacts, Deep-Sea Res. Part I-Oceanogr. Res. Pap., 57, 587-595, doi:10.1016/j.dsr.2010.01.005, 2010b.

Talley, L. D.: An Okhotsk sea-water anomaly-Implication for ventilation in the north Pacific, Deep-Sea Res. I, 38, S171-S190, 1991.

Thomas, A. C., Carr, M. E., and Strub, P. T.: Chlorophyll variability in eastern boundary currents, Geophys. Res. Lett., 28, 34213424, 2001.

Timmermann, A., Krebs, U., Justino, F., Goosse, H., and Ivanochko, T.: Mechanisms for millennial-scale global synchronization during the last glacial period, Paleoceanography, 20, PA4008, doi:10.1029/2004pa001090, 2005.

Tribovillard, N., Algeo, T. J., Lyons, T., and Riboulleau, A.: Trace metals as paleoredox and paleoproductivity proxies: An update, Chem. Geol., 232, 12-32, doi:10.1016/j.chemgeo.2006.02.012, 2006. van Geen, A. and Husby, D. M.: Cadmium in the California current system: Tracer of past and present upwelling, J. Geophys. Res.Ocean., 101, 3489-3507, 1996.

Waelbroeck, C., Labeyrie, L., Michel, E., Duplessy, J. C., McManus, J. F., Lambeck, K., Balbon, E., and Labracherie, M.: Sealevel and deep water temperature changes derived from benthic foraminifera isotopic records, Quaternary Sci. Rev., 21, 295-305, 2002.

Wagner, J. D. M., Cole, J. E., Beck, J. W., Patchett, P. J., Henderson, G. M., and Barnett, H. R.: Moisture variability in the southwestern United States linked to abrupt glacial climate change, Nat. Geosci., 3, 110-113, 2010.

Wang, H., Stumpf, A. J., Miao, X., and Lowell, T. V.: Atmospheric changes in North America during the last deglaciation from dune-wetland records in the Midwestern United States, Quaternary Sci. Rev., 58, 124-134, doi:10.1016/j.quascirev.2012.10.018, 2012.

Zaytsev, O., Cervantes-Duarte, R., Montante, O., and GallegosGarcia, A.: Coastal upwelling activity on the pacific shelf of the Baja California Peninsula, J. Oceanogr., 59, 489-502, 2003.

Ziegler, M., Jilbert, T., de Lange, G. J., Lourens, L. J., and Reichart, G. J.: Bromine counts from XRF scanning as an estimate of the marine organic carbon content of sediment cores, Geochem. Geophys. Geosyst., 9, 5009, doi:10.1029/2007gc001932, 2008. 